\title{
1. Building an architecture for political influence: Atlas and the transnational institutionalization of the neoliberal think tank
}

Marie-Laure Salles-Djelic

\section{INTRODUCTION}

In a famous 1970 New York Times article, Milton Friedman argued for the principled separation and strict division of labor between political and economic spheres (Friedman 1970). Political elites should set and monitor basic (and limited) rules of the game in independence. Meanwhile, economic elites should be left to maximize utility within the bounds of these rules. Such principled and strict separation, however, is difficult to reconcile with empirical observation. Historically, politics and economic affairs have always been connected one way or another (Goldthwaite 1987; Mills 1956). The nature, the extent and the mechanisms of this interplay, however, evolve through time and with changing contexts. In particular, the dynamics of power and influence between economic and power elites vary significantly (Martin and Swank 2012; Mills 1956; Pearson 1997). In non-market and state-run economies, political elites tend to have the upper hand. In market societies, the situation may be more complex.

In market societies, politics and politicians can still steer and orient the conduct of economic affairs through the formalization and monitoring of regulations and rules of the game. In parallel, however, economic actors can deploy various strategies to influence politics and politicians. The game then becomes a complex circular one where political actors may have the capacity to impose rules and structures on economic actors but those rules and structures might be strongly influenced, if not shaped ultimately, by economic actors themselves. Globalization and corporate capitalism's progress across the world have made that circular interplay all the more striking. Today, more than 50 of the largest hundred economic entities in the world are corporations - the others are nation states. Those large 
transnational corporations are not only major economic players. Their size and transnational reach also makes them powerful political actors (Bakan 2004; Perrow 1991).

Corporations are powerful political actors in different ways. First, they have an intense direct impact on politics and politicians - and hence rule-making and rule monitoring - through large-scale lobbying and/or political or campaign financing (Bebchuk and Jackson 2013; Borisov et al. 2014; Igan et al. 2009; Smith 2000; Woll 2008). They have this kind of impact at the local, national or even transnational - for example European - level. Second, the exercise of corporate social responsibility can be reinterpreted as one more expression of the political role and impact of business (Scherer and Palazzo 2007). Corporations are making consequential political decisions as they compensate for 'failed states' (Chomsky 2006), act through delegation from disengaging states (Singer 2008) or become increasingly involved in transnational multi-stakeholder rule making (Djelic 2011). Third, there is an even more subtle way in which politics and the corporate world interact. Corporations are themselves infused with certain ideologies and hence politics that frame and shape their strategies, structures, processes and behaviors. These ideologies and politics that infuse corporations also have a tendency to influence and impact the world outside and beyond corporate boundaries. In particular, they find their way to politicians and to the political sphere. Different kinds of actors contribute actively to this infusion of particular political programs both within corporations and in the political sphere - consulting firms, lobby and advocacy groups, academics (from business schools and economics departments mostly), as well as a dense ecology of think tanks and research institutes.

Over the last 40 years or so, neoliberalism has become the 'new dominant regime of truth' (Burgin 2012; Mirowski and Plehwe 2009; Djelic 2006; Foucault [1978] 2004; Harvey 2005) with a significant performative impact, through time, on national policymaking (Campbell and Pedersen 2001) and on dynamics of transnational governance (Lee and McBride 2007). This powerful ideological program translates into concrete politics with influence both in the corporate and political worlds. Of particular interest here is the carrier and boundary-spanning role of a dense ecology of neoliberal think tanks and research institutes that has come to be structured over the past four decades (Cockett 1995; Aligica and Evans 2009; Jackson 2012; Medvetz 2012). Neoliberal think tanks espouse a market- and business-friendly ideology and have made it their mission to champion, spread, defend and entrench, as widely and deeply as possible and in a multiplicity of contexts, this ideology and its associated politics.

In this chapter, I am interested in the historical dynamics of emergence 
of this dense ecology of neoliberal think tanks. Starting from the setting up, in 1955, of the Institute of Economic Affairs (IEA) in Britain, I explore the role of an organization, Atlas, that was created to replicate and diffuse the success of the IEA and to 'litter the world' with free-market think tanks (Blundell 2001). As I explore the founding of Atlas and its early years of operation, I am particularly interested in the process through which the organizational form of the 'neoliberal think tank' came to be constructed, diffused and progressively institutionalized during that period. Through this historical case study, I hope to contribute to our understanding of the contemporary interplay between business and politics. I unpack potent albeit subtle and indirect - mechanisms of influence that have largely been neglected in the literature. Neoliberal think tanks were constructed to shape and spread ideological, political and practice templates and to help crystallize and stabilize them across the world both in the corporate and in the political world. The key, as Hayek argued in 1949, was 'to shape public opinion' and orient it towards a belief in the superiority of market solutions and economic logics (Hayek 1949, p. 417). Politics and policymaking would then necessarily have to adapt, under pressure from an evolving and mobilized public opinion - and this would occur across a great diversity of institutional and cultural contexts.

\section{METHODS AND DATA}

This article builds upon an in-depth historical case study (Skocpol 1984). Historical case studies belong to the category of 'process research' (Langley 1999). They are particularly well suited to exploring processual sequences and bundles of causal patterns that lead up to an important situation (Skocpol 1984; Van de Ven and Sminia 2012). The 'situation' I am interested in is the contemporary existence of a dense ecology of neoliberal think tanks with ideological and political impact. And my focus is on the historical dynamics and causal sequences leading up to that 'situation'. As space is constrained, I focus my account on the early steps and sequences creating the conditions for such a 'situation' to emerge. I follow, hence, the early years of one particular organization, Atlas, from the context of its emergence to the role it played, during its first years of operation, in the diffusion and institutionalization across different parts of the world of a new organizational form - the neoliberal think tank. The period that is explored goes from 1955 and the creation by Antony Fisher of the first neoliberal think tank, the Institute of Economic Affairs (IEA) in London, through the creation of Atlas in 1981 and until Fisher's death in 1988.

The data presented reflect the classic combination, in historical case 
studies, of primary and secondary data. Primary data sources are 'forms of evidence produced during the historical period under investigation' (Witkowski and Jones 2006, p.72). Unfortunately, access to Atlas' full archives has been impossible. However, a wealth of primary documents is available from the website of Atlas as well as from a number of other sources. A number of personal archives (those of Margaret Thatcher and Friedrich Hayek in particular) as well as the websites and archives of a number of organizations connected to Atlas - some of which are available online - are all useful sources of information on the setting up and early development of Atlas. The reference section provides an exhaustive list of the websites and archives that have been consulted and exploited for the generation of this historical case study. As a complement, I have also used the documents that make up a 'history from within' the neoliberal constellation - books, memoirs and biographies. As much as possible, I have triangulated the information in those documents with available primary sources. I have also consulted and used existing secondary contributions by historians and social scientists. There is a broad secondary literature by now on the historical development of the neoliberal movement in general, a rapidly increasing production on the topic of neoliberal think tanks but nothing as yet on Atlas and its particular role in the neoliberal constellation.

\section{CONTEXTUALIZATION - BUILDING THE INSTITUTE OF ECONOMIC AFFAIRS}

In 1955, Sir Antony Fisher, a World War II British Air Force veteran turned chicken farmer, set up the Institute of Economic Affairs (IEA) in London. In the following years, Fisher himself constructed and spread the 'creation myth'. After reading a Reader's Digest version of Hayek's book, The Road to Serfdom, Fisher went to the London School of Economics in 1946 to meet Hayek in person and propose his services to the cause of free markets (Muller 1996). When Fisher suggested he could go into politics, Hayek countered with an alternative proposition:

Society's course will be changed only by a change in ideas. First you must reach the intellectuals, the teachers and writers with reasoned argument. It will be their influence on society, which will prevail and the politicians will follow. (As quoted in Blundell 2003, p. 17)

The seed for the IEA and the first neoliberal think tank had thus been planted. Fisher brought it alive in 1955, after he had accumulated sufficient financial resources through his entrepreneurial success with the mass 
production of chicken. To run the IEA, Fisher recruited Ralph Harris, a young intellectual from the Conservative Party (Blundell 2003, p. 17). Harris then convinced Arthur Seldon - a bright liberal economist - to join as editorial director. The IEA engaged in intense intellectual activism, producing and diffusing 'papers and pamphlets for an educated audience' (Blundell 2003, p. 21; Seldon 2005). It also relayed the work of Hayek and other prominent members of the still young Mont Pèlerin Society (Mirowski and Plehwe 2009). Initially, the period and the country were not conducive to free-market ideas - quite to the contrary:

We were a scorned, dismissed, heretical minority. There was a preordained path for the state to regulate, to plan and to direct - as in war, so in peace. If you questioned it, it was like swearing in church. At times this overwhelming consensus intimidated us, and we sometimes held back. We often felt like mischievous, naughty little boys. (Blundell 2003, p. 20)

By the beginning of the 1960s, though, the IEA had found a space and an audience in the intellectual ecology of Britain. Around the IEA and its numerous press and social events - where academics and other contributors presented and discussed papers with policy implications - the network of free-market supporters and champions became denser through time (Muller 1996; Seldon 2005). It brought together a great diversity of people from academia, the media, the professional world and business. By the mid-1970s, the Institute of Economic Affairs was in the process of asserting its intellectual influence in Britain. With the IEA, Fisher, Harris and Seldon had successfully institutionalized the prototype of a new kind of organization - the neoliberal think tank. This organization had four characteristic features. First, its mission was 'to conduct a war of ideas' and to champion 'market philosophy' (Muller 1996). Second, it would do so by attempting to influence those people Hayek called 'second hand dealers in ideas' (Hayek 1949) - the 'academic scribblers and intellectuals who shaped, promulgated and even advertised ideas, journalists, broadcasters, teachers, students and political commentators' (Muller 1996 p. 90).

Third, the organization refused allegiance to any political party and vowed not to receive any public or government funds to keep its 'independence'. Funding initially came from private individuals, and in particular from Fisher. Later on, private firms became important contributors (Muller 1996). Fourth, the IEA rapidly managed to co-opt academics into its activities and hence progressively developed academic and scientific rigor and legitimacy. All those features were striking and quite specific to the IEA then. They would soon become the defining markers of the neoliberal think tank as a new organizational form. 
The concrete influence of the IEA was confirmed in May 1979, when the Conservative Party won the British parliamentary elections by a wide margin and Margaret Thatcher became prime minister (Muller 1996, 101ff). On 18 May, she sent a warm thank you note to Ralph Harris (and to the IEA as a whole):

Let me thank you for what you have done for the cause of free enterprise over the course of so many years. It was primarily your foundation work, which enabled us to rebuild the philosophy upon which our Party succeeded in the past. The debt we owe to you is immense and I am very grateful. (Thatcher 1979)

In June 1979, Margaret Thatcher made Ralph Harris her first peer, raising him as Lord Harris of High Cross (Blundell 2008, p. 190). Harris liked to say that 'he was not a Thatcherite' but that Britain was lucky that 'Margaret Thatcher was an IEA-ite' (Wolf 2006).

\section{DIFFUSING AND INSTITUTIONALIZING THE NEOLIBERAL THINK TANK}

In the 1970s already, Fisher had in mind the idea of replicating the success of the IEA through the multiplication of parallel initiatives. As he made clear in 1977:

To those who ask for a concentrated effort I plead with all the power at my command for proliferation. We are getting near the truth; let it be propounded from as many sources as possible. (Frost and Moller 2008, p. 20)

In 1975, a Canadian businessman, Patrick Boyle, asked Fisher to come and help him set up what would become the Fraser Institute. Things, then, started to accelerate. Fisher was being contacted, from different parts of North America, to help with the launch of organizational 'brothers' and 'sisters' to the IEA; the Manhattan Institute in 1978 in New York, the Heritage Foundation in Washington or the Pacific Research Institute in San Francisco, where he and his wife moved in 1979.

\section{Building upon Early Success - Towards the Creation of Atlas}

After the political victory of Thatcher in 1979, Antony Fisher was more eager than ever to foster the proliferation of neoliberal think tanks beyond the shores of Britain, Canada or the United States. He tested, with a few persons, his idea of an organization that would be in charge of 
proliferation. On 1 January 1980, Hayek wrote back, giving him his full support:

I entirely agree with you that the time has come when it has become desirable and almost a duty to extend the network of institutes of the kind of the London Institute of Economic Affairs ... I am more convinced than ever that the method practiced by the IEA is the only one, which promises any results ... This ought to be used to create similar institutes all over the world and you have now acquired the special skill of doing it. (Hayek 1980)

The new organization Fisher had in mind would fulfill the mission of helping to set up neoliberal think tanks across the world. The Institute for Economic Affairs would serve as the prototype for the think tanks themselves and Fisher planned to build upon his recent experience as 'think tank entrepreneur' in Canada and in the United States. On 20 February 1980, he received another warm endorsement for that project, this time from Margaret Thatcher:

I applaud your aim to build on the success of the IEA in Europe, America and further afield. I believe it deserves the most urgent and generous support of all concerned with the restoration of the market economy as the foundation of a free society. (Thatcher 1980)

After winning the Nobel Prize in 1976, Milton Friedman had retired from the University of Chicago and settled in San Francisco. There, he was a visiting scholar at the Federal Reserve Bank of San Francisco and fellow at the Hoover Institution in Stanford (Taylor 2000). The Friedmans lived in the same apartment block as Antony Fisher and his wife (Friedman 2002). So, not only did Milton Friedman endorse Fisher's idea right away; he was also closely associated with the early development of the project.

The Atlas Economic Research Foundation (Atlas) was incorporated in the State of Delaware on 14 July 1981. The offices of Atlas were initially located in San Francisco, in the Mills Building at 220 Montgomery Street. In the summer of 1988, just after Antony Fisher died, Atlas moved its offices to George Mason University in Fairfax, Virginia - a few miles from Capitol Hill and the Washington power center. John Blundell then became the new president and stayed in that position until 1991 when he moved to the Institute of Economic Affairs (Frost and Moller 2008, p. 38).

The name Atlas has two possible origins. It can obviously refer to the Greek Titan who held up the world on his shoulder. In Greek mythology, though, Atlas is strong but not very smart, easily deceived by Ulysses. Archimedes, the Greek astronomer, proposed a rational reinterpretation of the Atlas myth that was, apparently, the source of inspiration for Antony 
Fisher (Frost and Moller 2008, p. 27). Archimedes purportedly said: 'Give me a place to stand and a lever long enough and I will move the world.' The lever, in our story, was the Institute for Economic Affairs prototype to be diffused across the world. In the neoliberal thought collective, however, Atlas is also easily associated with the work of Ayn Rand, in particular her best-selling book Atlas Shrugged. The official position of the Atlas Economic Research Foundation on the origin of its name is relatively non-committal:

The name was not derived from the book, in fact the word 'Atlas' in our name has to do with the global nature of our work. And although we share many of the free market values found in Atlas Shrugged and held by the Atlas Society and Ayn Rand Institute, we are quite separate organizations. (Atlas 2013b)

Atlas' beginnings were small. Pamela Lentz joined Atlas as full-time secretary/office manager on 1 January 1982. In 1985, Alejandro Chafuen, a young Argentinian with a PhD in economics from California (and a member of the Mont Pèlerin Society since 1980), joined the team (Chafuen 2011). Chafuen was president of Atlas from 1991 to 2009 and he remains a member of the board.

In the early period, Antony Fisher did most of the work with the support of his wife, Dorian (Chafuen 2011). The budget of Atlas, for the first year, was around $\$ 150,000$ (Chafuen 2011). Donors included a Canadian family that to this day desires to remain anonymous. The Sarah (Mellon) Scaife Foundation donated 30 percent of the initial budget and is still a major donor. The Scaife Foundation is a Pittsburg-based family foundation that gives large sums of money to many members of the neoliberal thought collective, and is arguably the 'leading financial supporter of the movement that reshaped American politics in the last quarter of the twentieth century' (Kaiser 1999, p. A1). Charles Brunie, Dorian Fisher (Antony's rich wife) and a number of private philanthropists from the United States and Canada were also among the early donors (Chafuen 2011).

\section{Fostering Proliferation - Atlas and the Early Diffusion of Neoliberal Think Tanks}

The main mission of Atlas, initially, was to expand the reach of the neoliberal agenda by fostering the rapid proliferation of think tanks on the model of the London IEA in different regions of the world. The idea was that those think tanks, just like the IEA had done in Britain, would 'influence public sentiment' across the world and that this would in turn 'make legislation possible' (Fisher 1985). During its early period, Atlas fostered the proliferation of think tanks in essentially two ways. First, it 
provided seed money. Even though amounts were small, this role of 'think tank angel' proved extremely important as it would start the engine', as it were. As Antony Fisher was keenly aware:

One of the difficulties in setting up an institute is to raise the money in the first place, because usually businessmen don't know what it is all about. They need to see the publications producing results by selling in universities and attracting media coverage. Without the product, fundraising is always slow. (Fisher 1981)

Second, Fisher and the small team around him played the role of coach and consultant. Building upon the experience accumulated throughout the 1970s with the first generation of neoliberal think tanks, they identified success factors and different ways to deal with obstacles. Atlas was not itself a think tank, nor did it 'run(s) or control(s) any institute' but it 'used the IEA's experience to advise an ever-growing family of independent institutes' (Atlas 1987).

The first investment ever of Atlas after 1981 was in a French institute the Institut Economique de Paris (IEP) (Fisher 1983). Pascal Salin, an economist, and Guy Plunier, a businessman, were the local team behind the IEP (Chafuen 2011). Even though this institute did not survive, Salin has remained very active in the fight for a revival of liberalism in France (Salin 2000). Fisher also put high hopes in John Goodman, a bright young scholar with a $\mathrm{PhD}$ in economics from Columbia. Atlas gave Goodman a starting grant of US\$20,000. This allowed him to launch in 1983 the National Center for Policy Analysis (NCPA) in Dallas, Texas. The Center would go on to become a highly influential think tank that worked extensively to diffuse 'new ideas' in the United States, particularly when it comes to the privatization and marketization of healthcare (NCPA 2013). In South America, Fisher started by helping Hernando de Soto, a Peruvian economist trained in Switzerland who went back to Peru in 1981 to found, with the help of Atlas, the Institute for Liberty and Democracy (ILD) (Chafuen 2011). The influence of Fisher and Atlas on the Institute for Liberty and Democracy was extremely significant, as de Soto later recalled:

It was on the basis of his (Fisher's) vision that we designed the structure of the ILD. He then came to Lima and told us how to structure the statutes, how to plan our goals, how to build the foundation, what to expect in the short and long term. (As quoted in Frost 2002)

Initially, the Institute for Liberty and Democracy fought for the institutionalization of private property rights in Peru. In 1987, de Soto wrote a book outlining a liberal agenda that would have a significant impact in Peru and in other developing countries across the world. The title chosen 
for that book - The Other Path - was provocative in itself, as it clearly referred to and confronted the powerful Shining Path Maoist movement, which was at that time extremely active and powerful in Peru (Atlas 1991).

In Iceland, Fisher set his sights on Hannes Gissurarson. With a small grant from Atlas, this young man launched the Jon Thorlaksson Institute in 1983. In 1985, he defended his $\mathrm{PhD}$ thesis in political science at Oxford University, with the title Hayek's Conservative Liberalism. The Jon Thorlaksson think tank was named after an Icelandic prime minister from the 1920s who had been a fervent champion of economic freedom. This think tank disappeared in 1988 but was in fact replaced by a new organization. The Icelandic Research Center for Innovation and Economic Growth is the 'direct heir to the Jon Thorlaksson Institute' and is registered with the tax authorities under the same identification number as the old institute (RNH 2013). Gissurarson is still today the academic director of that organization. In Australia, Fisher worked with Greg Lindsay in the early 1980s, as the latter was busy creating the Center for Independent Studies (Lindsay 1996). The Center for Research in Applied Economics in Italy, launched by Antonio Martino, was another institute that Atlas and Fisher helped create. Fisher also spearheaded or assisted projects in Mexico, Venezuela, Chile, Australia and Spain (Neubauer 2012). He even encouraged Eastern European researchers based in the United Kingdom to start working on the question of communism, with a view to a pending post-communist turn (Chafuen 2011).

By 1985, there were 26 organizational members in the constellation of neoliberal 'secondhand dealers of ideas' associated with Atlas. Fisher and/ or Atlas were behind the creation or development of almost all of them (Fisher 1985).

\section{CONNECTING THE THINK TANKS TO THE NEOLIBERAL THOUGHT COLLECTIVE}

Beyond its role in fostering the diffusion of neoliberal think tanks across the world, Atlas also had a significant impact during that period as a connector and mediating organization. It played a major role in facilitating the inscription of the various think tanks into what could be called the common neoliberal 'thought collective' (Mirowski and Plehwe 2009).

A first dimension of that inscription was the creation of a direct connection between the think tanks and their leaders and the intellectual core of the neoliberal movement, the Mont Pélerin Society (MPS), which Hayek had set up in 1947 (Djelic 2006; Mirowski and Plehwe 2009). A key mechanism was the co-optation of leaders of the early think tanks into the 
MPS. Among the 26 think tanks associated with Atlas in 1985, 20 had a leader who was by that date already a member of the Mont Pèlerin Society. In the following years, four more would be connected to the Mont Pèlerin through membership of the leader. In general, the connection between think tank leaders and the Mont Pélerin Society started either a few years before or after the setting up of the think tank. This points to two probable trajectories. Either, Antony Fisher scouted the individual in the context of Mont Pèlerin Society meetings and identified him/her as a promising future think tank leader. Alternatively, the think tank leader was brought into the core organization of the neoliberal 'thought collective' precisely because of his/her role in the building up of a successful think tank.

This proximity with the core meant that the think tanks were regularly involved in the activities of the MPS. The Institute of Economic Affairs helped organize the Oxford meeting of the MPS in 1959, and organized two further meetings in Scotland in 1968 and 1976. The Fraser Institute organized MPS regional meetings in Vancouver in 1983 and again in 1999. In the context of MPS meetings, the members of this 'thought collective' were regularly exposed to an intellectual orthodoxy that became increasingly controlled and powerful as conflicts and contradictions within the MPS were progressively expunged (Djelic 2006; Mirowski and Plehwe 2009).

A second important dimension of the inscription in a neoliberal 'thought collective' was the embeddedness of the intellectual activity of the various think tanks in a set of structuring references that were surprisingly homogeneous. Atlas helped diffuse the ideas of the core into the swelling ranks of neoliberal second-hand dealers of ideas. Greg Lindsay, the founder and leader of the Australian Center for Independent Studies made that very clear:

The strategy mapped out by Hayek in The Intellectuals and Socialism was one of working with people who transmit ideas to everyone else. I still think that is right ... We (the local institutes) are the retailers and wholesalers of ideas. (Lindsay 1996, p. 20)

Atlas financed, in that early period, the translation in different languages of some of the key texts of Hayek, Friedman and of the papers initially produced by the Institute for Economic Affairs. It also facilitated the reproduction and diffusion of materials produced by some of the older neoliberal think tanks (Chafuen 2011). The texts written by Friedrich von Hayek came close, in that context, to being a common 'sacred reference'. The Road to Serfdom (Hayek 1944) was not far from being the 'Bible' of the neoliberal community, or, more precisely, the Reader's Digest condensed version of The Road to Serfdom (Frost 2002). Hayek also wrote many texts 
and pamphlets for the IEA that were later on broadly reprinted, translated and circulated by Atlas. Between 1968 and 1983, Hayek wrote 13 such texts; on inflation, currency, trade unions, privatization, rent restriction or unemployment among others.

A third way in which Atlas fostered the inscription of individual think tanks into the neoliberal 'thought collective' was through its active involvement in the local organization of meetings and workshops. Atlas helped finance and organize local meetings and events, even securing in a number of cases the participation of core actors. For example, Antony Fisher convinced both Hayek and Friedman to come to France and give their support to Pascal Salin and his liberal colleagues, a few months before the creation of the Institut Economique de Paris (IEP) in 1982, and a few months after the election in France of a Socialist president, François Mitterrand (Brookes 2014, p. 15ff). In the early 1980s, Hayek and/or Friedman visited more or less all the countries where Fisher was busy helping with the development of a think tank: Iceland, Peru, Chile, Venezuela, Australia, France, Italy, Spain (Ebenstein 2003; 2007). In some cases, Fisher was there first and mobilized the help of Hayek or Friedman. In other cases, Hayek created the contact with Fisher when he felt that there was an interesting opportunity; this was the case for example in Peru with Hernando de Soto (Mitchell 2009). In the quite different local contexts they explored in that early period, Fisher and the Atlas team hence played the very important role of mediators. By bringing along with them the big names of the neoliberal 'thought collective', who by then were Nobel Prize winners, and mobilizing them around local events, they imbued local think tanks and their leaders with legitimacy and visibility. In the process, they buttressed weak and fragile initiatives.

\section{ATLAS OR THE 'MOTHER ORGANIZATION' - STUMBLING INTO THE NURTURING ROLE}

As a result of these efforts, the membership base of Atlas increased rapidly. In 1981, when he was launching Atlas, Fisher had claimed:

There are ten operating institutes using similar methods, fourteen more trying to get started, and at least sixteen other places where help would be effective. That would be a total of some forty institutes in thirty countries. (As quoted in Chafuen 2011)

By 1985, Fisher could already identify close to 30 think tanks across the world that were connected to Atlas (Fisher 1985). In the spring of 1988, a few months before Fisher died, Atlas was in touch with over forty 
institutes in twenty plus countries' - not too far from what Fisher had anticipated eight years before (Atlas 1988).

The original project of Antony Fisher, with the creation of Atlas, had been to foster and facilitate the development, around the world, of neoliberal think tanks modeled after the Institute for Economic Affairs (Fisher 1985; Friedman 2002). As this started to happen, in the early 1980s, Atlas 'bumped', as it were, into another necessary and complementary role. Atlas became a central hub for a transnational network in the making. Setting up think tanks was not enough; their founders also needed to create the conditions for them to 'sing in unison'. The Atlas team was rapidly convinced that 'in order to influence public opinion and ultimately public policy' across different countries, you needed 'choruses and not (multiple) solos' (Antony Fisher Speech May 1980, quoted in Chafuen 2013). Atlas, it turned out, would have to structure and nurture the emerging transnational community of neoliberal second-hand dealers in ideas (Djelic and Quack 2010).

In fact, this would become the principal role for Atlas starting in the 1990s. Those developments are beyond the scope of this chapter, but we identify here some of the early activities that Atlas launched in that direction in the early 1980s. The very structure of Atlas was, in reality, already a step in that direction. Sitting on the first board of Atlas, in July 1981, were leaders of some of the older Institutes: Ralph Harris (IEA), Patrick Boyle (Fraser), Charles Brunie (Manhattan) and Jim North (PRI). From the start, it seemed, Atlas was thought of as a 'common home'. Soon, Fisher launched the yearly Atlas International Workshops. The first one, in September 1983, took place in Vancouver, Canada, and was organized jointly with the Fraser Institute. Then followed Cambridge (UK), Sydney (Australia), Saint Vincent (Italy) and Indianapolis (US). In each case, the organization of the workshop was a joint effort between Atlas and the local Institute(s) inscribed in the Atlas constellation. And the Atlas meetings were systematically organized in conjunction with the meeting, that same year, of the Mont Pèlerin Society. The Atlas Workshops took place on the weekend before the start of the Mont Pèlerin Society meeting, which always began on a Sunday (Liberaal Archief 2005).

These international workshops were relatively small at the beginning and the main objective was to bring members of the emerging transnational community together, physically, at least once a year. The first workshop for which we have concrete information is the fifth Atlas Workshop, which took place in September 1986 in Indianapolis, with close to 100 participants (Atlas 1988). Three different groups of speakers presented. First, there were representatives of the 'old institutes': Harris (IEA), Michael Walker (Fraser), William Hammett (Manhattan), William Mellor (PRI), 
Alejandro Chafuen and Antony Fisher (Atlas). Second, was a group of representatives from the younger 'child Institutes' of Atlas: Greg Lindsay (CIS), John Goodman (NCPA), Hernando de Soto (ILD), Antonio Martino (CREA). Finally, there were a few invited participants; for example a secretary of state from the Thatcher government, an academic from Washington University, a retired manager and board member of the Heritage Foundation (who later contributed funding to Atlas) and a journalist from the Wall Street Journal (Atlas Workshop 1987). Interestingly, the program and application form for the Atlas Workshop clearly indicated that attending the workshop did not imply an automatic invitation to the Mont Pèlerin meeting (ibid.). Each year, the neoliberal constellation physically came together, but the way in which it did underscored the hierarchy and partial separation between the core and the layer of second-hand dealers in ideas. Still, the proximity of the two events, in time and space, was probably a good motivating mechanism for the young up-and-coming think tank leaders, who could thus hope to be invited, one day, to the mysterious meetings of the holy core.

\section{CONCLUSION}

According to Hayek, an intellectual revolution could only happen if the framing work of a core of utopian thinkers was relayed through time by increasing numbers of intellectual 'foot soldiers' (Hayek 1949). This layer of 'secondhand dealers in ideas' was essential to the architecture of influence that Hayek was thinking about, in the mid-1940s, to revive the (economic) liberal project. It would translate and disseminate the programmatic agenda of the core. The work of this second layer was about institution-building with two main objectives: to influence cognitive maps and 'public opinion' in many different local contexts and to impact, in time, political programs in different places, to generate the new 'governing force of politics' (Hayek 1949, p. 417).

When Antony Fisher created the Institute for Economic Affairs in 1955, he had in mind this programmatic structure, which he had discussed with Hayek himself. In all likelihood, however, he did not envision that this early initiative would come to have such a consequential impact. The path was clearly not an easy one and in the first period of this story, many accidental developments hindered or facilitated the proximate diffusion of a new type of organization - the neoliberal think tank. When Fisher created Atlas in 1981 it was built on slightly more solid ground. Atlas could build upon the success of the IEA and it was born in a much more favorable political context following the political triumph of Margaret Thatcher in Britain 
and of Ronald Reagan in the US. The objective thus shifted to taking the next steps, accelerating the process of diffusion and the expansion of neoliberal think tanks in many different parts of the world. Milton Friedman nicely summarized those different stages:

If Antony had done no more in the think-tank world (than creating the IEA), it would have been enough to put all believers in freedom in his debt. But after a digression to breeding green turtles, scientifically successful but commercially disastrous, he returned to breeding think tanks, at first on a retail basis, and then, with the establishment of the Atlas Economic Research Foundation, on a wholesale basis. (Friedman 2002)

When Fisher died in 1988, he had created a new organizational form - the neoliberal think tank. He had significantly contributed to both the design of that organizational form and to its diffusion and progressive institutionalization across a great variety of contexts. The neoliberal think tank, as a powerful 'secondhand dealer in ideas', was contributing considerably to the progressive emergence across a number of countries of a new institutional field - the field of neoliberal influence building. In the last years of his life, Fisher saw his vision come to fruition:

Numerous press clippings report how the institutes in the Atlas network are redefining the boundaries of 'politically impossible' policies worldwide ... 'This illustrates how institutes dedicated to the principles of the free market and private property are making a difference in the world,' commented Atlas Chairman Antony Fisher. (Atlas 1988)

By then, there were close to 40 neoliberal think tanks in more than 20 countries. According to DiMaggio, 'new institutions arise when organized actors with sufficient resources see in them an opportunity to realize interests that they value highly' (DiMaggio 1988, p. 14). DiMaggio calls those organized actors 'institutional entrepreneurs'. In that sense, Antony Fisher was indeed an 'institutional entrepreneur'. What this story shows, however, is that Fisher could not have accomplished what he did alone. The process described was a complex one, with ups and downs, unintended developments, the involvement of a multiplicity of other actors and resources and clearly different stages with evolving logics. The type of 'institutional entrepreneurship' at work here was not the heroic type, even though Fisher has unsurprisingly been hailed as a hero in the community he did so much to spearhead. I have shown instead that the process of institutional emergence in that context resulted 'from spatially dispersed, heterogeneous activities' (Lounsbury and Crumley 2007) and that it reflected complex collective interplays, ambiguous and unintended developments, as well as significant temporal sequencing (Djelic 2010). 
As it turns out, the story told here was only the beginning. Since 1988, the network of influence spanned and nurtured by Atlas has expanded in a striking way. Today Atlas boasts a membership of more than 400 think tanks in more than 70 nations across the world (Atlas 2013). As the numbers increased, the role of keeping the network together and of structuring and nurturing a transnational community of neoliberal think tanks has become both more important and more challenging for Atlas (Djelic and Quack 2010). How Atlas has managed to deal with that challenge since the late 1980 s is another interesting story. It is, however, beyond the scope of this chapter.

\section{REFERENCES}

Aligica, P.D. and A. Evans (2009), The Neoliberal Revolution in Eastern Europe, Cheltenham, UK and Northampton, MA, USA: Edward Elgar.

Bakan, J. (2004), The Corporation, London, UK: Robinson Publishing.

Bebchuk, L. and R. Jackson (2013), 'Shining light on corporate political spending', Georgetown Law Journal, 101, 923-67.

Borisov, A., E. Goldman and N. Gupta (2014), 'The corporate value of (corrupt) lobbying, working paper', at European Corporate Governance Institute http:// papers.ssrn.com/sol3/papers.cfm?abstract_id=2443104. Accessed 3 May 2017.

Brookes, K. (2014), 'Le rôle des clubs et des réseaux d'intellectuels libéraux dans la diffusion du néolibéralisme en France, Sciences Po Grenoble, Working Paper 16', at http://www.sciencespo-grenoble.fr/wp-content/uploads/2013/11/SPGWP16.pdf. Accessed 3 May 2017.

Burgin, A. (2012), The Great Persuasion: Reinventing Free Markets since the Great Depression, Cambridge, MA: Harvard University Press.

Campbell, J. and O. Pedersen (eds) (2001), The Rise of Neoliberalism and Institutional Analysis, Princeton, NJ: Princeton University Press.

Chomsky, N. (2006), Failed States, New York: Henry Holt \& Co.

Cockett, R. (1995), Thinking the Unthinkable, London: Fontana Press.

DiMaggio, P. (1988), 'Interest and agency in institutional theory', in L. Zucker (ed.), Institutional Patterns and Organizations, Cambridge, MA: Ballinger, pp. 3-32.

Djelic, M.L. (2006), 'Marketization: From intellectual agenda to global policy making', in M.L. Djelic and K. Sahlin-Andersson (eds), Transnational Governance, Cambridge, UK: Cambridge University Press, pp. 53-73.

Djelic, M.L. (2010), 'Institutional perspectives: Working towards coherence or irreconcilable diversity?', in G.J. Morgan, J.L. Campbell, C.C. Crouch, O.K. Pedersen and R. Whitley (eds), The Oxford Handbook of Comparative Institutional Analysis, Oxford, UK: Oxford University Press, pp. 15-40.

Djelic, M.L. (2011), 'From the rule of law to the law of rules', International Studies of Management and Organization, 41(1), 35-61.

Djelic, M.L. and S. Quack (eds) (2010), Transnational Communities, Cambridge, UK: Cambridge University Press.

Ebenstein, A. (2003), Friedrich Hayek: A Biography, Chicago: University of Chicago Press. 
Ebenstein, A. (2007), Milton Friedman: A Biography, New York: Palgrave Macmillan.

Foucault, M. [1978] (2004), Naissance de la Biopolitique, Paris: Seuil.

Friedman, M. (1970), 'The social responsibility of business is to increase its profits', The New York Times, 13 September 1970.

Frost, G. (2002), Anthony Fisher: Champion of Liberty, London: Profile Books.

Goldthwaite, R. (1987) 'The Medici Bank and the world of Florentine capitalism', Past \& Present, 114, 3-31.

Harvey, D. (2005), A Brief History of Neoliberalism, Oxford, UK: Oxford University Press.

Hayek, F. (1949), 'The intellectuals and socialism', University of Chicago Law Review, Spring, 417-33.

Igan, D., P. Mishra and T. Tressel (2009), 'A fistful of dollars: Lobbying and the financial crisis, IMF working paper', at http://www.imf.org/external/pubs/ft/ wp/2009/wp09287.pdf. Accessed 3 May 2017.

Jackson, B. (2012), 'The think tank archipelago: Thatcherism and neoliberalism', in B. Jackson and R. Saunders (eds), Making Thatcher's Britain, Cambridge, UK: Cambridge University Press, pp. 43-61.

Kaiser, R. (1999) 'Money, family name shaped Scaife, Washington Post, May 3', at http://www.washingtonpost.com/wp-srv/politics/special/clinton/stories/scaife main050399.htm. Accessed 3 May 2017.

Langley, A. (1999), 'Strategies for theorizing from process data', Academy of Management Review, 24, 691-710.

Lounsbury, M. and E. Crumley (2007), 'New practice creation: An institutional perspective on innovation', Organization Studies 28(7), 993-1012.

Martin, C. and D. Swank (2012), The Political Construction of Business Interests, Cambridge, UK: Cambridge University Press.

Medvetz, T. (2012), Think Tanks in America, Chicago: The University of Chicago Press.

Mills, C.W. (1956), The Power Elite, Oxford, UK: Oxford University Press.

Mirowski, P. and D. Plehwe (eds) (2009), The Road from Mont Pèlerin, Cambridge, MA: Harvard University Press.

Mitchell, T. (2009), 'How neoliberalism makes its world: The urban property rights project in Peru', in P. Mirowski and D. Plehwe (eds), The Road from Mont Pèlerin, Cambridge, MA: Harvard University Press, pp. 386-416.

Muller, C. (1996) 'The Institute of Economic Affairs: Undermining the post-war consensus', Contemporary British History, 10(1), 88-110.

Neubauer, R. (2012), 'Dialogue, monologue or something in between? Neoliberal think tanks in the Americas', International Journal of Communications, 6 , 2173-98.

Pearson, M. (1997), China's New Business Elite, Oakland, CA: University of California Press.

Perrow, C. (1991) 'A society of organizations', Theory \& Society, 20, 725-62.

Scherer, A.G. and G. Palazzo (2007), 'Toward a political conception of corporate social responsibility', Academy of Management Review, 32, 1096-120.

Singer, P. (2008), Corporate Warriors, Ithaca, NY: Cornell University.

Smith, M. (2000), American Business and Political Power, Chicago: University of Chicago Press.

Skocpol, T. (1984), Vision and Method in Historical Sociology, Cambridge, UK: Cambridge University Press. 
Van de Ven, A. and H. Sminia (2012), 'Aligning process questions, perspectives and explanations', in M. Schultz, S. Maguire, A. Langley and H. Tsoukas (eds), Constructing Identity in and around Organizations, Oxford, UK: Oxford University Press, pp. 306-19.

Witkowski, T. and B. Jones (2006), 'Qualitative historical research in marketing', in R. Belk (ed.), Qualitative Historical Research Methods in Marketing, Cheltenham, UK and Northampton, MA, USA: Edward Elgar, pp. 70-82.

Woll, C. (2008), Firm Interest, Ithaca, NY: Cornell University Press.

\section{Atlas - History from Within}

Blundell, J. (2001), 'Waging the war of ideas, London: IEA', at http://www.iea.org. uk/sites/default/files/publications/files/upldbook226pdf.pdf. Accessed 3 May 2017.

Blundell, J. (2008), Margaret Thatcher, New York: Algora Publishing.

Blundell, J. (2011), Ladies for Liberty, New York: Algora Publishing.

Chafuen, A. (2011), 'Atlas Economic Research Foundation early history', at http:// www.chafuen.com/atlas-economic-research-foundation-early-history. Accessed 3 May 2017.

Chafuen, A. (2013), 'Fisher quotes', at http://www.chafuen.com/fisherquotes. Accessed 3 May 2017.

Frost, G. and D. Moller (2008), 'Antony Fisher, champion of liberty condensed version, London: IEA', at http://www.iea.org.uk/publications/research/antonyfisher-champion-of-liberty. Accessed 3 May 2017.

\section{Think Tanks and Their Leaders}

Edwards, L. (1997), The Power of Ideas: The Heritage Foundation at 25 Years, Jameson Books.

Fraser (1999), 'Challenging perceptions: 25 years of influential ideas', at http://www. fraserinstitute.org/uploadedFiles/fraserca/Content/About_Us/Who_We_Are/25th _Retrospective.pdf. Accessed 3 May 2017.

Fraser (2004), 'The Fraser Institute at 30: a retrospective', at http://www.fraserinsti tute.org/uploadedFiles/fraserca/Content/About_Us/Who_We_Are/30th_Retrospe ctive.pdf. Accessed 3 May 2017.

Gissurarson, H. (2013), 'Reports of capitalism's demise exaggerated. Speech at the University of Iceland, February 19', at http://www.rnh.is/?p=3492. Accessed 3 May 2017.

Lindsay, G. (1996), 'The CIS at twenty - Greg Lindsay talks to Andrew Norton, Policy, Winter: 16-21', at https://www.cis.org.au/images/stories/policymagazine/1996-winter/1996-12-2-andrew-norton.pdf. Accessed 3 May 2017.

Seldon, A. (2005), The IEA, the LSE and the Influence of Ideas, Indianapolis, IN: Liberty Fund.

Seldon, A. and R. Harris (1977), Not from Benevolence, Kingston, RI: University of Rhode Island.

Wolfe, T. (2004), 'The Manhattan Institute at 25', in Manhattan Institute (ed.), Turning Intellect into Influence, Auckland, NZ: Reed Press, pp. 29-30. 


\section{Websites}

ASI (2013), Adam Smith Institute Website, at http://www.adamsmith.org/. Accessed 3 May 2017.

Atlas (2013a), Atlas Network Website, at http://atlasnetwork.org/. Accessed 3 May 2017.

Atlas (2013b), Frequently Asked Questions, Atlas Economic Research Foundation, at http://atlasnetwork.org/blog/2010/11/frequently-asked-questions-2/\#ref9. Accessed 3 May 2017.

DeSmogBlog (2010), Mont Pèlerin Directory, at http://www.desmogblog.com/sites/ beta.desmogblog.com/files/Mont $\% 20$ Pelerin $\% 20$ Society $\% 20$ Directory $\% 202010$. pdf. Accessed 3 May 2017.

Fraser (2013), Fraser Institute Website, at http://www.fraserinstitute.org/. Accessed 3 May 2017.

HF (2013), Heritage Foundation Website, at http://www.heritage.org/. Accessed 3 May 2017.

MI (2013), Manhattan Institute Website, at http://www.manhattan-institute.org/. Accessed 3 May 2017.

NCPA (2013), National Center for Policy Analysis - History, at http://www.ncpa. org/about/national-center-for-policy-analysis-history. Accessed 3 May 2017.

PRI (2013) Pacific Research Institute, at http://www.pacificresearch.org/about/prishistory/ Accessed 3 May 2017.

RNH (2013), Icelandic Research Center for Innovation and Economic Growth, at http://www.rnh.is/?page_id=346 Accessed 3 May 2017.

\section{Personal Pages and Biographical Information}

Boyle, P. (2013) at http://www.fraserinstitute.org/programs.aspx?pageid=64424510 36\&terms $=$ Patrick+Boyle. Accessed 3 May 2017.

Brunie, C. (2013), at http://www.hudson.org/learn/index.cfm?fuseaction=staff_bio\& eid=BrunChar. Accessed 3 May 2017.

Butler, E. (2013), at http://eamonnbutler.com/about/. Accessed 3 May 2017.

Butler, S. (2013), LinkedIn Profile.

Persico, J. (1991), The Lives and Secrets of William Casey, Penguin Books.

Casey, B. (2013), at http://billcasey.ca/. Accessed 3 May 2017.

Feulner, E. (2013), at http://www.heritage.org/about/staff/f/edwin-feulner. Accessed 3 May 2017.

Harris, R. (2000), 'Interview of Ralph Harris by PBS - Commanding Heights', at http://www.pbs.org/wgbh/commandingheights/shared/minitextlo/int_ralphharris. html\#8. Accessed 3 May 2017.

Mellor, W. (2013), at http://www.ij.org/wmellor-2. Accessed 3 May 2017.

Murray, C. (2013), at http://www.aei.org/scholar/charles-murray/. Accessed 3 May 2017.

Pipes, S. (2013), LinkedIn Profile.

Pirie, M. (2013), at http://eamonnbutler.com/about/. Accessed 3 May 2017.

Walker, M. (2013), at http://www.fraserinstitute.org/author.aspx?id=15364\&txID= 3266. Accessed 3 May 2017.

Wolf, M. (2006), 'Obituary Lord Harris of High Cross, Financial Times, October 19’, at http://mobi.fcpp.org/publication.php/1557. Accessed 3 May 2017. 


\section{Archives and Interviews}

Atlas (1987), Atlas Economic Research Foundation - Recent Highlights, May, Issue 6, at http://atlasnetwork.org/blog/2010/11/highlights-archives/. Accessed 3 May 2017.

Atlas (1988), Atlas Economic Research Foundation - Highlights, Spring, at http://atlasnetwork.org/blog/2010/11/highlights-archives/. Accessed 3 May 2017.

Atlas Workshop (1987), Atlas - Indianapolis Seminar, 5-6 September: at https:// docs.google.com/a/essec.edu/viewer? $\mathrm{a}=\mathrm{v} \&$ pid= $=$ sites\&srcid $=$ Y2hhZnVlbi5jb218d 3d3fGd4OjU3NTRkZjRiNGRiMmQ1YzM. Accessed 3 May 2017.

Fisher, A. (1981), 'Letter to a businessman in Jamaica', reprinted in A. Chafuen, Fisher Quotes, at http://www.chafuen.com/fisherquotes. Accessed 3 May 2017.

Fisher, A. (1983), 'Pourquoi l'IEA? Conférence prononcée à l'Institut Economique de Paris le 29 septembre 1982', Liberté économique et progrès social, $\mathrm{n}^{\circ}$ 46-47, Octobre.

Fisher, A. (1985) 'Atlas presentation and promotion video', at: http://www.youtube. com/watch? $=$ nW8ukG8WdQg. Accessed 3 May 2017.

Hayek, F. (1980), 'Letter to Antony Fisher. January 1', at http://www.margaretthatcher. org/document/117149. Accessed 3 May 2017.

Liberaal Archief (2005), Inventory of the General Meeting Files Mont Pèlerin Society (1947-98), at www.liberaalarchief.be. Accessed 3 May 2017.

Taylor, J. (2000), 'An interview with Milton Friedman, Conducted on May 2 in San Francisco', at http://www.stanford.edu/ johntayl/Onlinepaperscombinedby year/2001/An_Interview_with_Milton_Friedman.pdf. Accessed 3 May 2017.

Thatcher, M. (1979), 'Note to Ralph Harris, May 18', at http://www.marga retthatcher.org/document/117145. Accessed 3 May 2017.

Thatcher, M. (1980), 'Letter to Antony Fisher. February 20', at http://www.marga retthatcher.org/document/117154. Accessed 3 May 2017.

Thatcher, M. (1993), 'The new world order, speech at the Fraser Institute, November 8', at http://www.margaretthatcher.org/document/108325. Accessed 3 May 2017.

Van Offelen, J. (2005), 'Preface by a former Belgian minister, member of the Mont Pèlerin Society to the inventory of the general meetings files', Ghent: Liberaal Archiev, at www.liberaalarchief.be. Accessed 3 May 2017. 